\title{
Comparison of topical zinc oxide and silver sulfadiazine in burn wounds: an experimental study
}

\author{
Yanık yarası tedavisinde topikal çinko oksit ile \\ gümüş sülfadiazinin karşılaştırılması: Deneysel çalışma \\ Kemal ARSLAN, ${ }^{1}$ Ömer KARAHAN, ${ }^{1}$ Ahmet OKUŞ, ${ }^{1}$ Yaşar ÜNLÜ, ${ }^{2}$ \\ Mehmet Ali ERYILMAZ, ${ }^{1}$ Serden AY, ${ }^{1}$ Barış SEVINÇ ${ }^{1}$
}

\section{BACKGROUND}

We aimed to compare the effects of topical zinc oxide and topical silver sulfadiazine in the treatment of partial-thickness burn wounds.

\section{METHODS}

The study was conducted with 20 New Zealand rabbits, and burn wounds were created by a brass probe. The animals were randomly divided into two groups. The burns were treated with zinc oxide (Group O) or silver sulfadiazine (Group S) with daily application. The wound healing process was followed both clinically and histopathologically. We determined the days at which $50 \%$ and $80 \%$ re-epithelization was observed.

\section{RESULTS}

The mean time for $50 \%$ and $80 \%$ re-epithelization was 21.4 and 25.4 days in Group $\mathrm{O}$ and 25.8 and 30.2 days in Group $\mathrm{S}$, respectively $(\mathrm{p}<0.001)$. The mean score for wound colonization was lower in Group O. The difference was statistically significant at weeks $2,3,4$, and $6(\mathrm{p}<0.001)$. In the histopathological examination, the thicknesses of the epidermis, dermis and scar tissue were $0.12 \mathrm{~mm}, 3.80 \mathrm{~mm}$ and $244 \mathrm{~mm}$ in Group O, and $0.16 \mathrm{~mm}, 4.76 \mathrm{~mm}$ and $3.16 \mathrm{~mm}$ in Group $\mathrm{S}$, respectively $(\mathrm{p}<0.001)$.

\section{CONCLUSION}

In this experimental burn study, zinc oxide was more effective than silver sulfadiazine in terms of epithelization, dermis maturation and scar formation.

Key Words: Zinc oxide; silver sulfadiazine; partial-thickness burn.

\section{$\boldsymbol{A M A C}$}

Bu çalışmada, yanık yaralarında yaygın olarak kullanılan çinko oksit ve gümüş sülfadiazinin tedavi etkileri karşılaştırıldı.

\section{GEREÇ VE YÖNTEM}

Yeni Zelanda cinsi 20 tavşanda pirinç propla yanık yarası oluşturuldu. Tavşanlar rastgele iki gruba ayrıldı. Yanıklar günlük uygulamayla birinci grupta çinko oksitle (Grup O), ikinci grupta (Grup S) gümüş sülfadiazinle tedavi edildi. Yara iyileşmesi klinik ve histopatolojik olarak takip edildi. Yara ölçümleri yapıldı ve $\% 50$ ve $\% 80$ reepitelizasyona ulaştığı günler belirlendi.

\section{BULGULAR}

Ortalama $\% 50$ ve $\% 80$ reepitelizasyona ulaşma süreleri Grup O’da sirasiyla 21,4 ve 25,4 gün, Grup S'de 25,8 ve 30,2 gündü $(\mathrm{p}<0,001)$. Yara kolonizasyonu ise 1, 2, 3, 4, 5 ve 6. haftalarda ortalama olarak Grup $O^{\prime}$ da daha düşüktü. Fark 2, 3, 4 ve 6. haftalarda anlamlı idi $(\mathrm{p}<0,001)$. Histopatolojik değerlendirme sonucunda Grup O'da epidermis, dermis ve skar dokusunun kalınlıkları sırasıyla 0,12, 3,80 ve $2,44 \mathrm{~mm}$ idi. Grup S'de ise $0,16,4,76$ ve $3,16 \mathrm{~mm}$ olarak bulundu $(\mathrm{p}<0,001)$.

\section{SONUÇ}

Bu deneysel çalışmada, çinko oksit yanık tedavisinde epitelizasyon, epidermis maturasyonu ve skar oluşumunda gümüş sülfadiazinden daha etkili bulunmuştur.

Anahtar Sözcükler: Çinko oksit; gümüş sülfadiazin; parsiyel kalınlıktaki yanık.

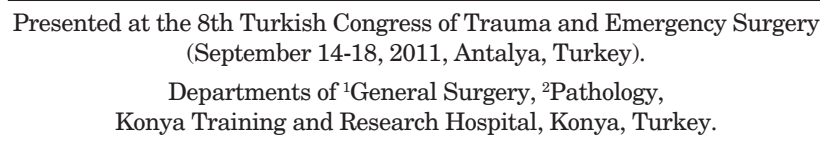

8. Ulusal Travma ve Acil Cerrahi Kongresi’nde sunulmuștur (14-18 Eylül 2011, Antalya).

Konya Eğitim ve Araştırma Hastanesi, ${ }^{1}$ Genel Cerrahi Kliniği, ${ }^{2}$ Patoloji Bölümü, Konya. 
In the treatment of burns, the aim is to treat burns, prevent infections and achieve the best functional and aesthetic results in a shorter time with lower costs. While healing burn wounds, a topical agent should decrease the rates of mortality and morbidity by preventing bacterial contamination and sepsis. The agent should also be easily accessible. An ideal agent with those properties has yet to be marketed. In the topical treatment of burn wounds, $1 \%$ silver sulfadiazine (SSD) pomade is the most commonly used agent worldwide. ${ }^{[1]}$ SSD has been shown to decrease bacterial contamination, to hasten epithelization and to delay wound contraction..$^{[2-8]}$ However, SSD is also known to delay wound healing and separation of scar tissue, to cause atrophic and hypertrophic scars, especially more than three weeks after the applications, to have renal toxicity, to cause leukopenia, and to carry a risk for resistance. ${ }^{[9-19]}$

Zinc is an essential element for the human body, and at the meeting of the World Union of Wound Healing Societies in Paris in 2004, it was accepted as having potential benefits in wound healing. ${ }^{[20]}$ There are studies showing the benefits of systemic and topical use of zinc in wound healing. It is also reported that zinc accelerates the wound healing process when applied on open wounds. ${ }^{[21]}$

To our knowledge, no study exists in the literature comparing the effects of local application of SSD and oxide zinc ointment $(\mathrm{OZO})$ in burn wounds. Therefore, the present study was designed to compare the effects of topical SSD and OZO in experimental partial-thickness burns in rabbits.

\section{MATERIALS AND METHODS}

\section{Study design}

Permission was obtained from the ethical board of Meram Medical School of Selçuk University. The study was designed under the criteria of the Health Guide for the Care and Use of Laboratory Animals by the National Institutes of Health (NIH Publication No: 86-23, Revised 1985 Bethesda). The research was conducted at the Experimental Research Center of Selçuk University. The weight of rabbits ranged from 3200-3600 g. The rabbits were accommodated in a $12 / 12$ hour light and dark cycle at $22-26^{\circ} \mathrm{C}$ and fed with a standard rabbit diet. As an analgesic, $100 \mathrm{mg} / 5$ $\mathrm{ml}$ of ibuprofen was administered via drinking water after the formation of burns. The rabbits were accommodated individually and approached with appropriate equipment to prevent contamination.

Before the study, punch biopsies as samples were obtained from eight rabbits to determine the thicknesses of normal epidermis and dermis. Mean values obtained from these samples were accepted as normal values.

Partial-thickness burns were formed in 20 adult New Zealand rabbits. The rabbits were divided into two groups. OZO 20\% was used in Group 1 (Group OZO), and SSD 1\% was used in Group 2 (Group SSD). The healing period was followed up clinically and histopathologically.

Five parameters were used in the determination of wound healing:

1. Days when $50 \%$ and $80 \%$ of re-epithelization was observed.

2. The score for wound colonization.

3. The histopathologic thickness of the epidermis.

4. The histopathologic thickness of the dermis.

5. The histopathologic thickness of the scar issue.

\section{Burn formation}

Anesthesia was achieved by a single dose of intramuscular $6 \mathrm{mg} / \mathrm{kg}$ of xylazine hydrochloride (Rompun, Bayer, $23.32 \mathrm{mg} / \mathrm{ml}$ ) and $50 \mathrm{mg} / \mathrm{kg}$ of ketamine hydrochloride (Ketalar, Parke-Davis, $50 \mathrm{mg} / \mathrm{ml}$ ). The back region of the rabbits was shaved and cleaned with $10 \%$ of povidone-iodine solution (Kim-Pa, Poviiodeks, $10 \%$ povidone-iodine). A specially designed brass probe with $10 \mathrm{~cm}^{2}$ of surface area $(2.5 \times 4 \mathrm{~cm}$ diameter) was used for the formation of burns (Fig. 1a). Having been sterilized in boiling water for 5 minutes, the probe was applied to the skin of anesthetized rabbits for 15 seconds with no pressure. Using this procedure, second-degree partial-thickness burns were formed (Figs. 1b, c). After the formation of burns, all the rabbits were placed and kept in individual cages.

\section{Local treatment}

Group O was treated with OZO and Group S with SSD. OZO was formed with $20 \%$ zinc oxide and $80 \%$ Vaseline. OZO can be found commercially as $20 \%$ of Oxide de Zinc (ORO zinc cream, ORO drugs). SSD was formed from 1\% SSD and 99\% paraben, and can commercially be found as $1 \%$ Silvadiazin cream (Toprak Drug Co.). According to our treatment protocol, the drugs were administered as a thin layer on the wounds once per day. Then, all wounds were protected with non-stick cotton and sterile gauze with adhesive elastic bandage (Setanet ${ }^{\circledR}$ No: 3 ) and changed on a daily basis (Fig. 1d).

\section{Assessment of wound healing}

This study was continued for six weeks after the formation of burns. Each wound was clinically observed meticulously, and digital photos were taken with a camera (Sony ${ }^{\circledR}$ CyberShot DSC-W120) every three days during the following six weeks. At week 6 , skin samples were collected, and wounds were as- 

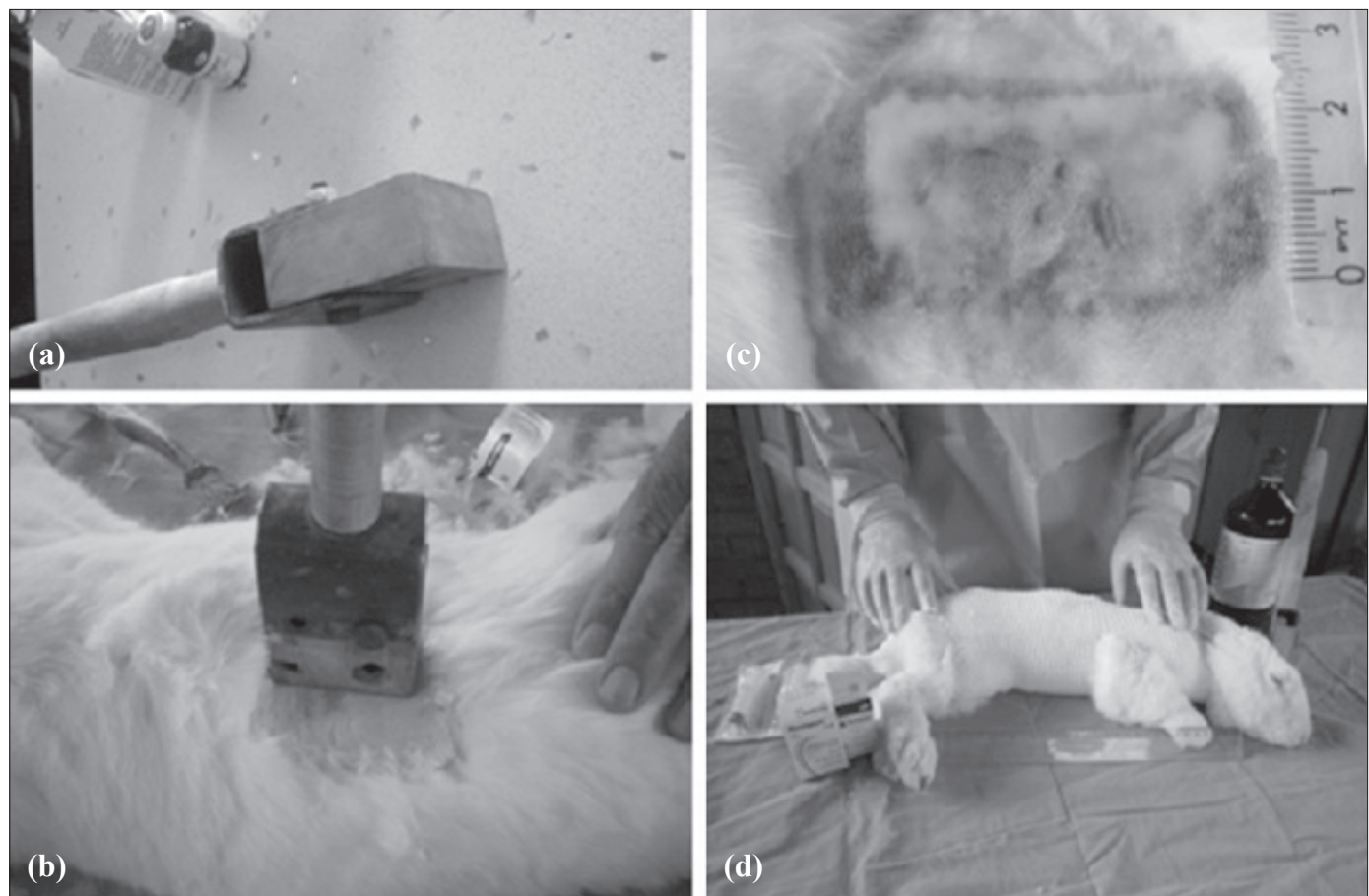

Fig. 1. The application of brass and burn formation.

sessed histologically. All the clinical and histological assessments of wounds were performed in a blinded fashion. At every change of dressings, wound healing was examined by an experienced clinician (a surgeon in the burn unit), and general comments were recorded (Fig. 2).

\section{Assessment of re-epithelization}

During the study, the photos of wounds were taken once every three days after cleaning with serum physiologic. The photos were taken from a distance of $20 \mathrm{~cm}$, in the same room under the same lighting conditions by the same researcher. The photos were
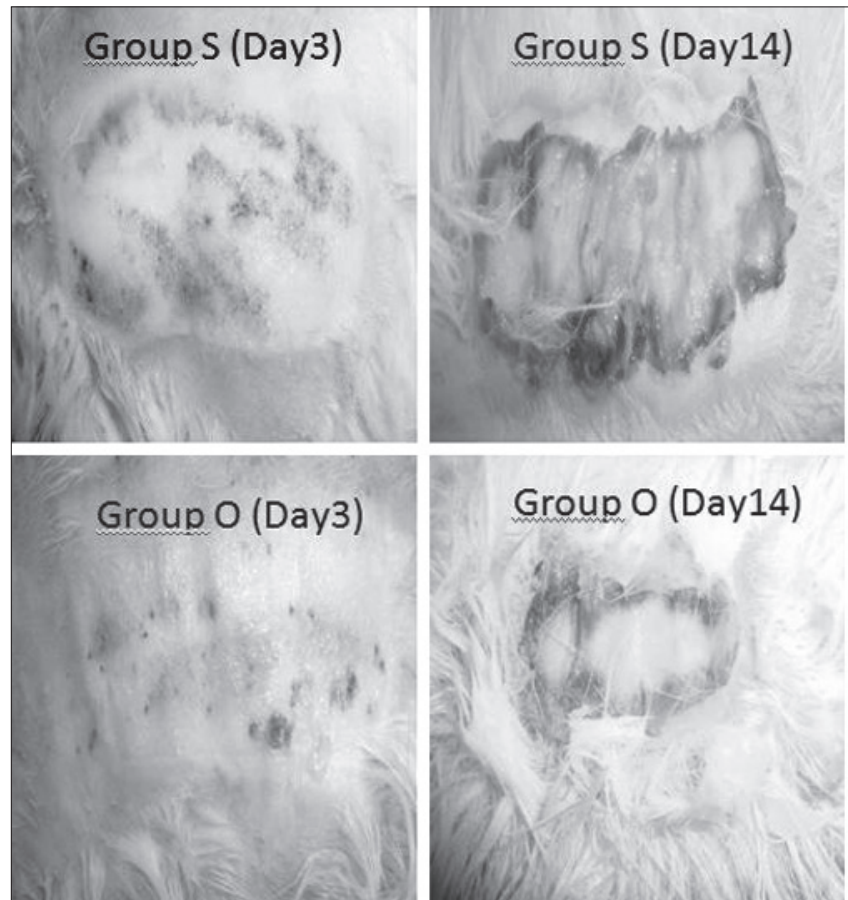
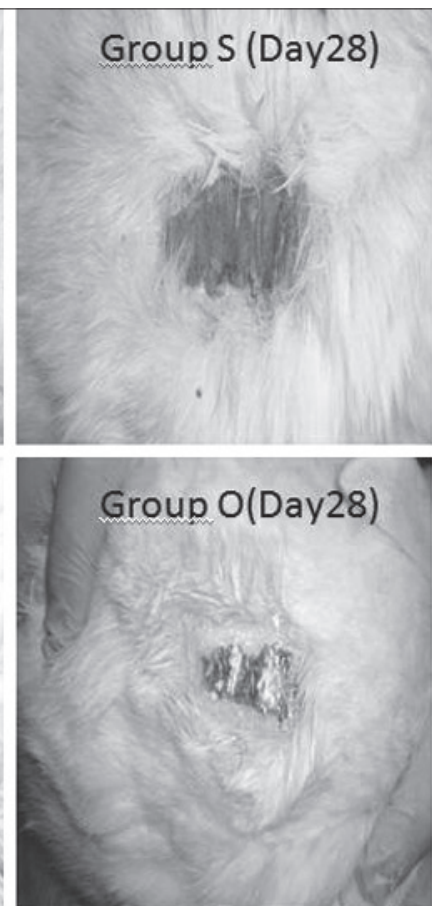
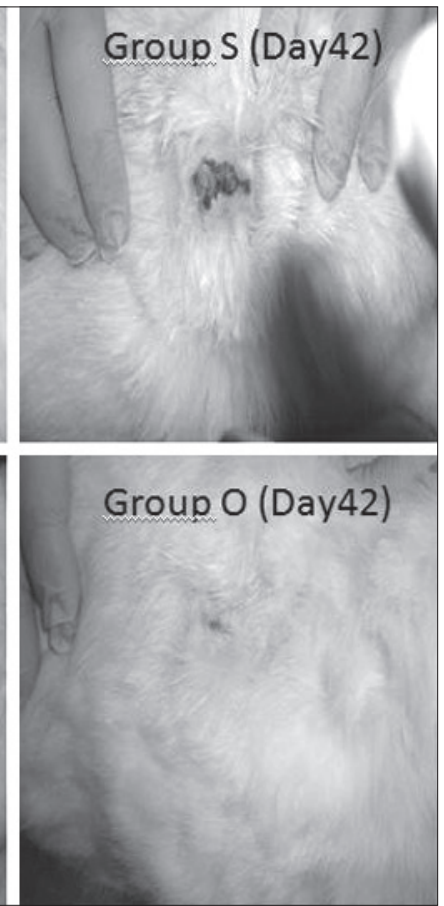

Fig. 2. Burn wounds on days 3, 14, 28, and 42 . 


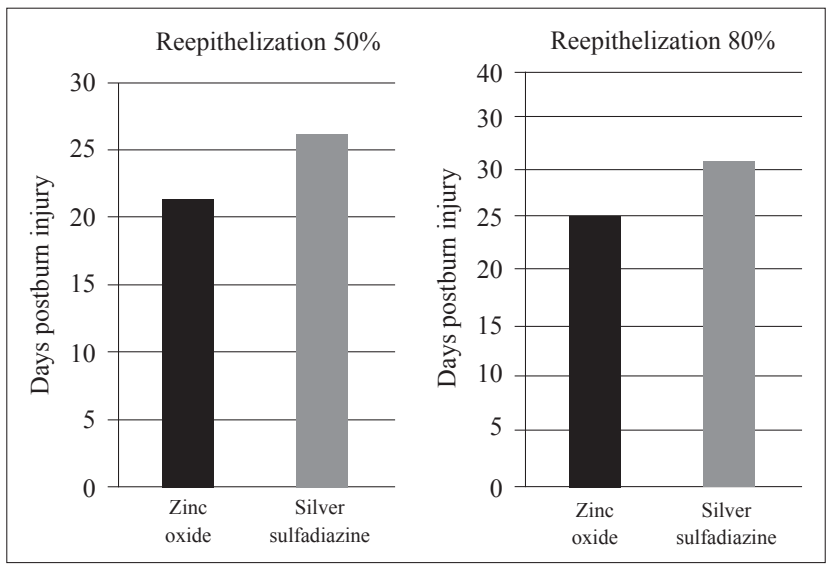

Fig. 3. Times to $50 \%$ and $80 \%$ re-epithelization.

evaluated under the criteria of NIH Image J program (Image J ver: $1.44 \mathrm{p}$, Wayne Rasband, NIH, USA). The margins of burn areas were marked and measured, and the measurements were recorded. The rate of reepithelization areas was calculated with the following formula:

Percentage of re-epithelization $=$ first burn area current burn area/first burn area.

The days on which $50 \%$ and $80 \%$ of re-epithelization was observed were detected for each rabbit.

\section{Assessment of wound colonization}

Wound colonization was assessed according to exudation, purulent efflux, efflux odor, erythema, and edema. A score between 0 and 3 was given to each assessment as follows: 0: No finding of colonization, 1 : Mild exudation and odor, 2: Erythema, moderate purulent efflux, exudation, and odor, and 3: Severe exudation, purulent efflux, odor, edema, and erythema.

Each assessment was performed by the same blinded researcher, who was unaware of the scores of rabbits determined before and during the treatment.

\section{Histopathological assessment}

The study was continued for six weeks and discontinued at the end of week 6 . At the end of the study, all the rabbits were sacrificed after their photos were taken. Full-thickness skin samples at burn areas were resected. Skin samples were preserved in formaldehyde solution and stained with hematoxylin-eosin (HE) and Masson trichrome dyes. The thicknesses of the epidermis, dermis and scar tissues were blindly evaluated through the NIH Image J program. In the assessment, the biopsy results of healthy rabbits prior to the study were accepted as normal values.

\section{Statistical analysis}

Collected data were analyzed using the Statistical Package for the Social Sciences (SPSS) 13.0 for Windows program. The values were evaluated as

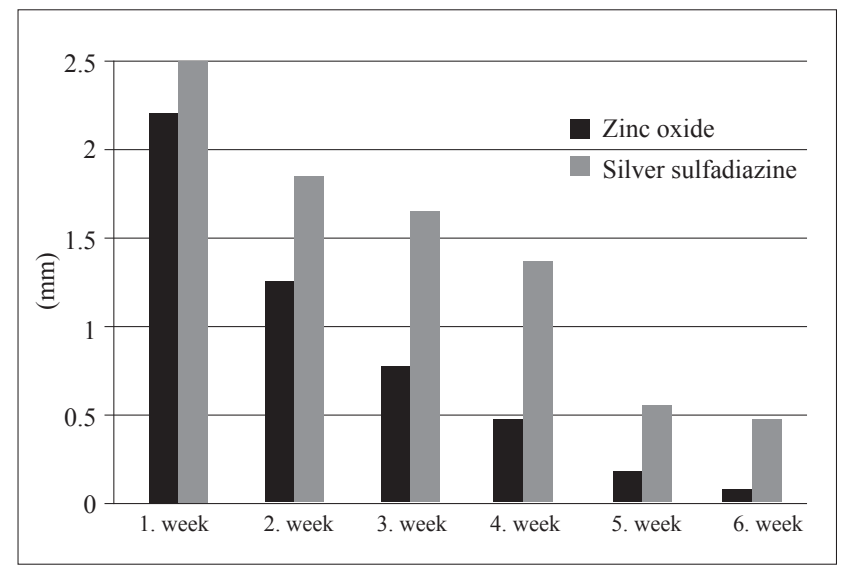

Fig. 4. Wound colonization in the OZO and SSD groups.

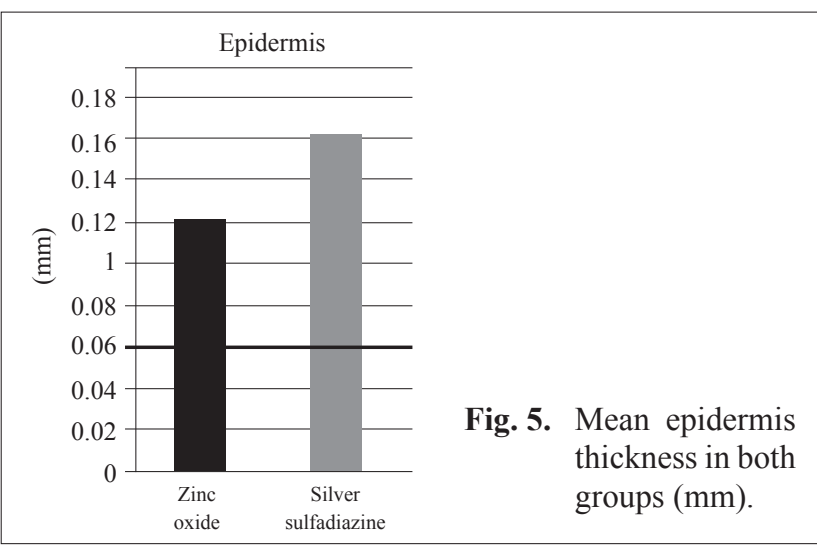

mean \pm SD. Student's $t$ test was used for comparison of the groups. A p value lower than 0.05 was accepted to be significant.

\section{RESULTS}

At the beginning of the study, all the burn wounds were similar. At the end of six weeks, no unhealed wounds were present.

\section{Result of re-epithelization}

The mean time for $50 \%$ of re-epithelization was 21.4 days in the OZO group and 25.8 days in the SSD group $(\mathrm{p}<0.001)$. The mean time to $80 \%$ of re-epithelization was 25.4 days in the OZO group and 30.2 days in the SSD group $(p<0.001)$. Re-epithelization of burn wounds was faster in Group OZO compared to Group SSD (Fig. 3).

\section{Wound colonization}

The scores of wound colonization were lower in Group O than in Group S within all weeks. However, these differences were significant only at weeks 2, 3, 4 , and $6(\mathrm{p}<0.05)$ (Fig. 4).

\section{Thickness of epidermis}

The mean thickness of the epidermis was $0.12 \mathrm{~mm}$ in Group OZO and $0.16 \mathrm{~mm}$ in Group SSD $(\mathrm{p}<0.001)$. 

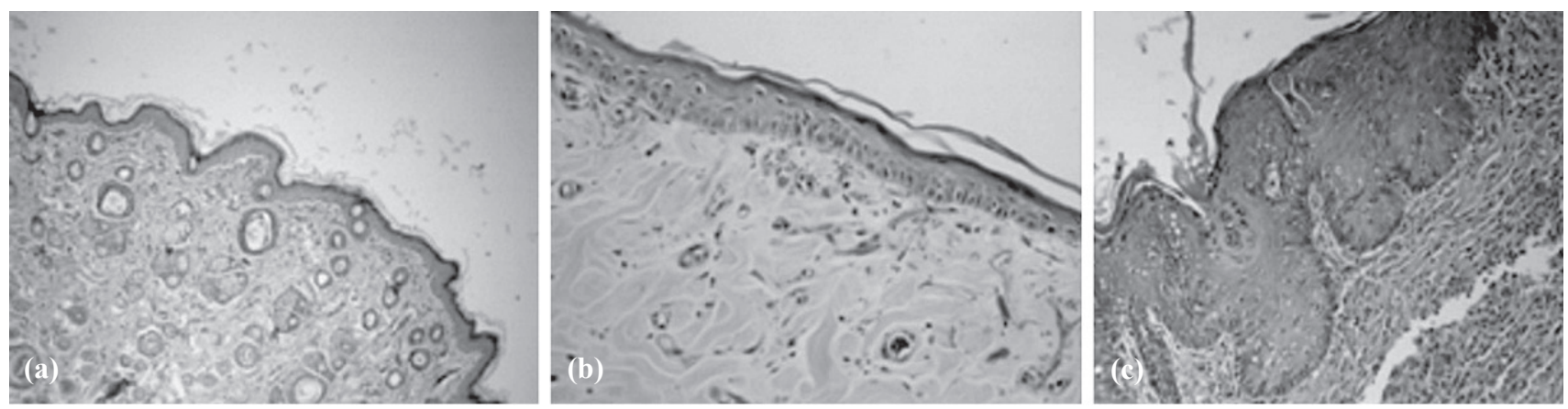

Fig. 6. (a) Histopathologic appearance of normal epidermis; (b) histopathologic appearance of epidermis of a rabbit treated by OZO; c: histopathologic appearance of epidermis of a rabbit treated by SSD. (OZO: Zinc oxide, SSD: Silver sulfadiazine)

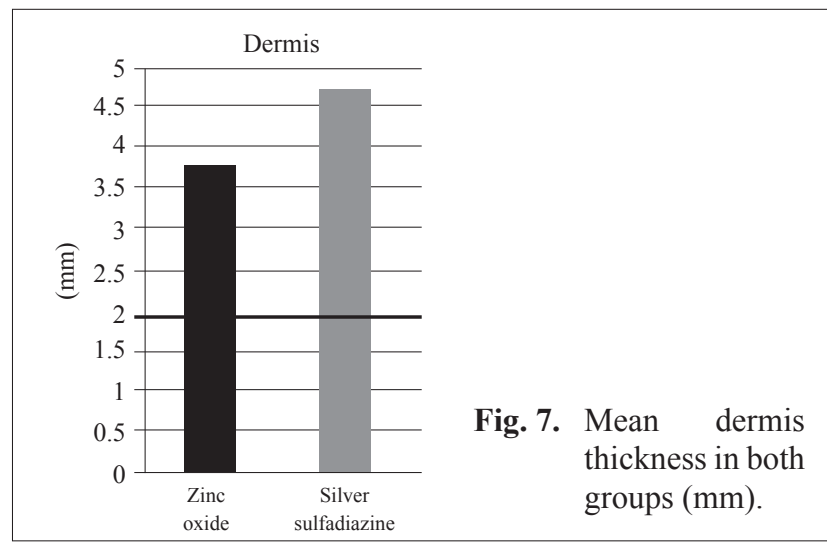

These values were higher than normal values, indicating that epidermal maturation was better in Group OZO than Group SSD (Fig. 5). The histopathologic appearances of normal epidermis, of epidermis from a rabbit treated with OZO and of epidermis from a rabbit treated with SSD are presented in Figures 6a, 6b and $6 \mathrm{c}$, respectively.

\section{Thickness of dermis}

In both groups, the histologically detected thicknesses of the dermis were higher than normal values $(3.8 \mathrm{~mm}$ in Group OZO and $4.7 \mathrm{~mm}$ in Group SSD), and the difference was statistically significant $(p<0.001)$ (Fig. 7). The histopathologic appearances of normal dermis, of dermis from a rabbit treated with
$\mathrm{OZO}$, and of dermis from a rabbit treated with SSD are presented in Figures 8a, b and c, respectively.

\section{Thickness of scar tissue}

The mean thicknesses of scar tissue were $2.4 \mathrm{~mm}$ in Group OZO and $3.2 \mathrm{~mm}$ in Group SSD $(\mathrm{p}<0.001)$. The scar tissue was significantly thinner in Group OZO compared to Group SSD (Fig. 9). The histopathological appearances of scar tissue in rabbits treated with OZO and SSD are shown in Figures 10a and b, respectively.

\section{DISCUSSION}

Burns are one of the most important health issues. Topical treatment is very important in the treatment of burns, and multiple agents have been used for this purpose. Some have been used for a long time; however, others have only recently appeared in the literature. An ideal topical agent should heal the wound in a shorter period with the best results, decrease the rates of mortality and morbidity by preventing bacterial contamination and sepsis, and be easily accessible and cheaper. As agents with such properties have yet to be identified or manufactured, studies to discover the ideal agent are ongoing. As the main part of the study, the effects of OZO on burn wounds were investigated, and the results were compared with those obtained with SSD. Recently, SSD has emerged as the most commonly used topical agent in burn wounds
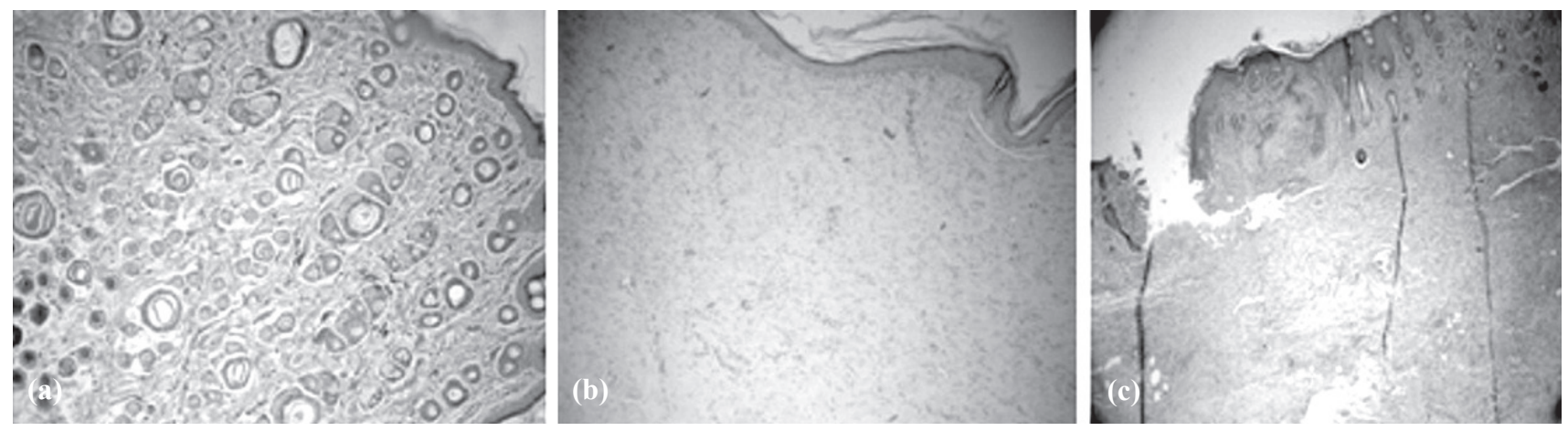

Fig. 8. (a) Histopathologic appearance of normal dermis; (b) histopathologic appearance of dermis of a rabbit treated by OZO; (c) histopathologic appearance of dermis of a rabbit treated by SSD. (OZO: zinc oxide, SSD: silver sulfadiazine). 


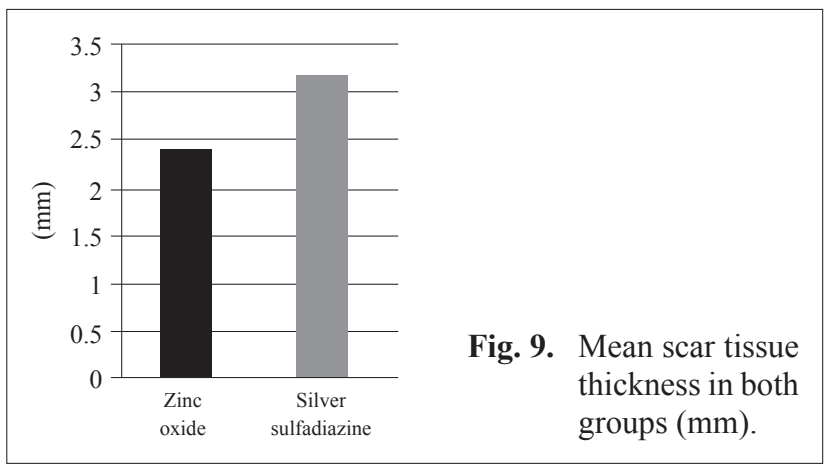

due to its antimicrobial effects. ${ }^{[1]}$

Silver contained resolved by SSD has a preventive effect by terminating most of the microorganisms, even fungi. ${ }^{[2]}$ It also accelerates the wound healing process through the inhibition of matrix metalloproteinases and increases the epithelization. ${ }^{[3-8]}$ Studies opposed to SSD can also be found in the literature. In a study by Maghsoudi et al., ${ }^{[9]}$ wet gauze dressings were reported to give better results than SSD in the treatment of burn wounds. The same study showed that SSD delays wound healing. Likewise, in a randomized controlled study by Khorasani et al. ${ }^{[10]}$ comparing aloe vera with SSD, it was concluded that wound healing was better in the aloe vera group and that SSD delays re-epithelization in burn wounds. SSD was also determined to delay the separation of scar tissue in deep wounds. ${ }^{[10-14]}$ Hypertrophic and atrophic scar formation can be seen in the treatment of SSD, especially in processes longer than three weeks. ${ }^{[15,16]}$ It was also reported that renal toxicity resolves after the treatment with SSD is discontinued. ${ }^{[17]}$ SSD may cause transient leukopenia, probably due to bone marrow toxicity. ${ }^{[18]}$ In the light of such data, it may be suggested that SSD is not an ideal topical agent in the treatment of burn wounds.

The significance of zinc has been known in medical science since ancient times. ${ }^{[19-21]}$ Recent data show that zinc is found in more than 300 enzymes in the human body and also has preventive effects against infections.
[22-24] At the meeting of the World Union of Wound Healing Societies in Paris in 2004, zinc was accepted to have potential benefits in wound healing. ${ }^{[20]}$ The defect of zinc-finger transcription factors in mRNA coding growth factors causes impaired wound healing. ${ }^{[25,26]}$ In a rat burn model, it was reported that the zinc level increases to $15-20 \%$ at the margin of the wound in the first 24 hours, and the level reaches 30\% when the epidermal proliferation and granulation tissue are at maximum level. The more the zinc level decreases, the more mitotic activity decreases, and then scar maturation occurs. ${ }^{[27-29]}$ Topical application of zinc decreases the rate of debris and necrotic material and increases the epithelization. ${ }^{[30-33]}$ According to Kietzmann, ${ }^{[35]}$ locally applied zinc accelerates the healing of ulcerated skin. According to various randomized controlled studies, topical application of zinc has beneficial effects on leg ulcers, pressure ulcers and diabetic foot ulcers. ${ }^{[25,33,36-38]}$ In light of these data, zinc may be suggested to be closely related to wound healing. However, no study has been reported or encountered in the literature about the effects of OZO on burn wounds. In several previous studies, zinc was used topically for both normal skin and open wounds; as a result of these studies, no systemic toxic effects were mentioned after the absorption. ${ }^{[27-30]}$ Therefore, in our study, investigation of the systemic effects of zinc was considered to be unnecessary, consistent with previous studies.

In order to determine the effects of zinc on burn wounds, OZO was used in a rabbit burn model, and the effects of zinc were compared to those obtained from the use of SSD. In Group OZO, the times when $50 \%$ and $80 \%$ of re-epithelization were observed were found to be 4 and 5 days shorter, respectively $(p<0.001)$. The period ranging from one to four days is very important in the treatment of burn wounds with zinc in human and animal wounds. ${ }^{[39-41]}$ As a result, a four- or five-day healing period gained through the treatment of OZO makes it more advantageous compared to SSD.
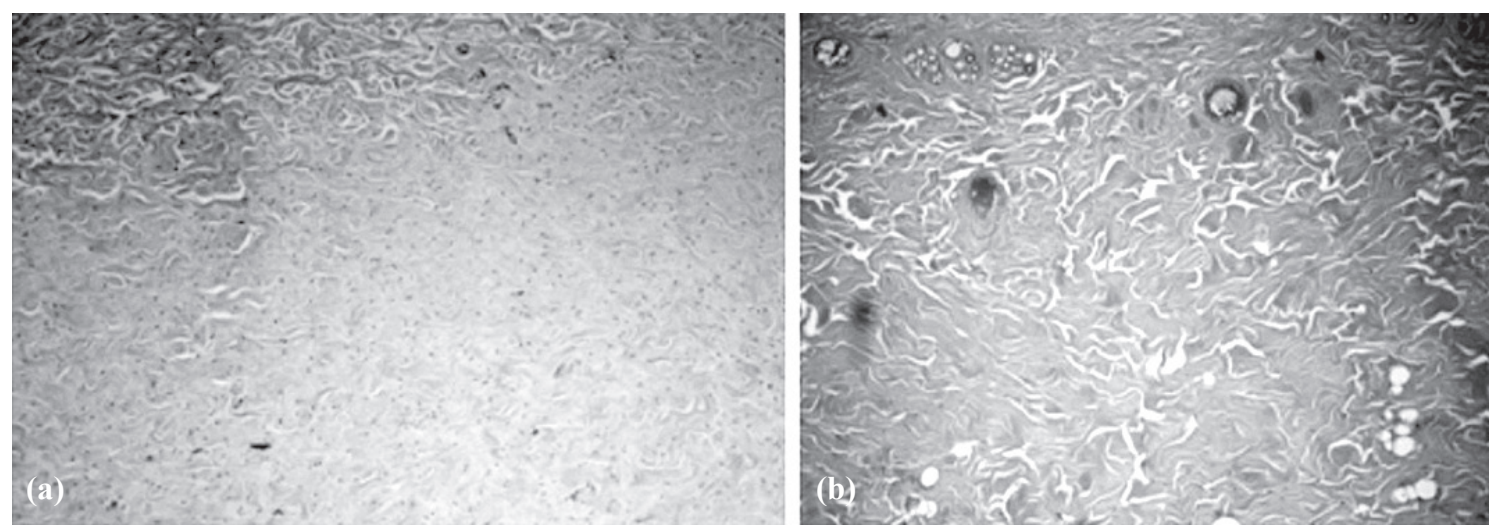

Fig. 10. (a) Histopathological appearance of scar tissue of a rabbit treated by OZO, (b) histopathological appearance of scar tissue of a rabbit treated by SSD. (OZO: zinc oxide, SSD: silver sulfadiazine) 
The score of wound colonization was lower in Group OZO than in Group SSD at all weeks. However, this difference was only significant at weeks 2,3 , 4 , and $6(\mathrm{p}<0.005)$. This parameter may be suggested to show the superiority of OZO in the treatment of burn wounds. Another criterion of burn wound healing determined in the present study was the thickness of the epidermis, dermis and scar tissues. The thicknesses of epidermis and dermis measured histopathologically were higher in both groups compared to normal values. The mean thickness of the epidermis was $0.12 \mathrm{~mm}$ in Group OZO and $0.16 \mathrm{~mm}$ in Group SSD ( $<<0.001)$. The mean thickness of the dermis was also lower in Group OZO than Group SSD $(p<0.001)$. Likewise, the mean thickness of scar tissue was lower in Group OZO compared to Group SSD $(\mathrm{p}<0.001)$.

In this study, the duration to re-epithelization, scale of wound colonization, and thicknesses of the epidermis, dermis and scar tissues were used to assess the process of burn wound healing. Given all these parameters, OZO was determined to be superior to SSD in the treatment of partial-thickness burn wounds. Considering the adverse effects of SSD, the superiority of OZO became more prominent. As no burn study related to the use of topical zinc is available at present, our results could not be compared to the literature. Therefore, further experimental and clinical studies regarding the effects of zinc oxide on burn wounds are needed to provide better results for medical science. Our study concluded that partial-thickness burns may be treated with OZO, and newer studies should address these issues for application in humans.

In conclusion, in an experimental burn model, zinc oxide was indicated to be superior to SSD when used topically. Clinicians should be aware of the beneficial effects of zinc oxide in the treatment of burn wounds.

\section{REFERENCES}

1. Papini RP, Wilson AP, Steer JA, McGrouther DA, Parkhouse $\mathrm{N}$. Wound management in burn centres in the United Kingdom. Br J Surg 1995;82:505-9.

2. Vloemans AF, Soesman AM, Suijker M, Kreis RW, Middelkoop E. A randomised clinical trial comparing a hydrocolloid-derived dressing and glycerol preserved allograft skin in the management of partial thickness burns. Burns 2003;29:702-10.

3. Gilman \& Goodman. Pharmacologic basis of therapeutics. 5th ed. New York: McMullin; 1975. p. 930.

4. Warriner R, Burrell R. Infection and the chronic wound: a focus on silver. Adv Skin Wound Care 2005;18:2-12.

5. Atiyeh BS, Costagliola M, Hayek SN, Dibo SA. Effect of silver on burn wound infection control and healing: review of the literature. Burns 2007;33:139-48.

6. Wright JB, Lam K, Buret AG, Olson ME, Burrell RE. Early healing events in a porcine model of contaminated wounds: effects of nanocrystalline silver on matrix metalloproteinases, cell apoptosis, and healing. Wound Repair Regen
2002; 10:141-51.

7. Demling RH, Leslie DeSanti MD. The rate of re-epithelialization across meshed skin grafts is increased with exposure to silver. Burns 2002;28:264-6.

8. Lansdown AB. Silver. 2: Toxicity in mammals and how its products aid wound repair. J Wound Care 2002;11:173-7.

9. Maghsoudi H, Monshizadeh S, Mesgari M. A comparative study of the burn wound healing properties of salinesoaked dressing and silver sulfadiazine in rats. Indian J Surg 2011;73:24-7.

10. Khorasani G, Hosseinimehr SJ, Azadbakht M, Zamani A, Mahdavi MR. Aloe versus silver sulfadiazine creams for second-degree burns: a randomized controlled study. Surg Today 2009;39:587-91.

11. Cho Lee AR, Leem H, Lee J, Park KC. Reversal of silver sulfadiazine-impaired wound healing by epidermal growth factor. Biomaterials 2005;26:4670-6.

12. Poon VK, Burd A. In vitro cytotoxity of silver: implication for clinical wound care. Burns 2004;30:140-7.

13. Hollinger MA. Toxicological aspects of topical silver pharmaceuticals. Crit Rev Toxicol 1996;26:255-60.

14. Sawhney CP, Sharma RK, Rao KR, Kaushish R. Long-term experience with 1 per cent topical silver sulphadiazine cream in the management of burn wounds. Burns 1989;15:403-6.

15. Sheridan RL, Petras L, Lydon M, Salvo PM. Once-daily wound cleansing and dressing change: efficacy and cost. J Burn Care Rehabil 1997;18:139-40.

16. Klasen HJ. A historical review of the use of silver in the treatment of burns. II. Renewed interest for silver. Burns 2000;26:131-8.

17. Dickinson SJ. Topical therapy of burns in children with silver sulfadiazine. N Y State J Med 1973;73:2045-9.

18. Chaby G, Viseux V, Poulain JF, De Cagny B, Denoeux JP, Lok C. Topical silver sulfadiazine-induced acute renal failure. [Article in French] Ann Dermatol Venereol 2005;132:891-3. [Abstract]

19. Choban PS, Marshall WJ. Leukopenia secondary to silver sulfadiazine: frequency, characteristics and clinical consequences. Am Surg 1987;53:515-7.

20. Lansdown AB, Mirastschijski U, Stubbs N, Scanlon E, Agren MS. Zinc in wound healing: theoretical, experimental, and clinical aspects. Wound Repair Regen 2007;15:2-16.

21. Prasad AS. Zinc: an overview. Nutrition 1995;11:93-9.

22. Jones PW, Williams DR. The use and role of zinc and its compounds in wound healing. Met Ions Biol Syst 2004;41:13983.

23. O'Dell BL. Zinc plays both structural and catalytic roles in metalloproteins. Nutr Rev 1992;50:48-50.

24. Vallee BL, Falchuk KH. The biochemical basis of zinc physiology. Physiol Rev 1993;73:79-118.

25. Agren MS, Ostenfeld U, Kallehave F, Gong Y, Raffn K, Crawford ME, et al. A randomized, double-blind, placebocontrolled multicenter trial evaluating topical zinc oxide for acute open wounds following pilonidal disease excision. Wound Repair Regen 2006;14:526-35.

26. Sum EY, O’Reilly LA, Jonas N, Lindeman GJ, Visvader JE. The LIM domain protein Lmo4 is highly expressed in proliferating mouse epithelial tissues. J Histochem Cytochem 2005;53:475-86.

27. Zhu CH, Ying DJ, Mi JH, Zhang W, Dong SW, Sun JS, et al. The zinc finger protein A20 protects endothelial cells from burns serum injury. Burns 2004;30:127-33.

28. Lansdown AB, Sampson B, Rowe A. Sequential changes in 
trace metal, metallothionein and calmodulin concentrations in healing skin wounds. J Anat 1999;195:375-86.

29. Savlov ED, Strain WH, Huegin F. Radiozinc studies in experimental wound healing. J Surg Res 1962;2:209-12.

30. Agren MS, Franzén L. Influence of zinc deficiency on breaking strength of 3-week-old skin incisions in the rat. Acta Chir Scand 1990;156:667-70.

31. Keefer KA, Iocono JA, Ehrlich HP. Zinc-containing wound dressings encourage autolytic debridement of dermal burns. Wounds 1998;10:54-8.

32. Lansdown AB. Influence of zinc oxide in the closure of open skin wounds. Int J Cosmet Sci 1993;15:83-5.

33. Apelqvist J, Larsson J, Stenström A. Topical treatment of necrotic foot ulcers in diabetic patients: a comparative trial of DuoDerm and MeZinc. Br J Dermatol 1990;123:787-92.

34. Gang RK. Adhesive zinc tape in burns: results of a clinical trial. Burns 1980;7:322-5.

35. Kietzmann M. Improvement and retardation of wound healing: effects of pharmacological agents in laboratory animals.
Vet Dermatol 1999;10:83-8.

36. Agren MS, Strömberg HE. Topical treatment of pressure ulcers. A randomized comparative trial of Varidase and zinc oxide. Scand J Plast Reconstr Surg 1985;19:97-100.

37. Brandrup F, Menné T, Agren MS, Strömberg HE, Holst R, Frisén M. A randomized trial of two occlusive dressings in the treatment of leg ulcers. Acta Derm Venereol 1990;70:2315 .

38. Strömberg HE, Agren MS. Topical zinc oxide treatment improves arterial and venous leg ulcers. Br J Dermatol 1984;111:461-8.

39. Greenhalgh DG. Wound healing. In: Herndon DN, editor. Total burn care. London: W.B. Saunders; 2002. p 523-95.

40. Fu X, Li X, Cheng B, Chen W, Sheng Z. Engineered growth factors and cutaneous wound healing: success and possible questions in the past 10 years. Wound Repair Regen 2005; 13:122-30.

41. Singer AJ, Clark RA. Cutaneous wound healing. N Engl J Med 1999;341:738-46. 